\title{
Mainstreamová kultura mládeže
}

\author{
Mainstream Youth Culture \\ Michaela Pyšňáková
}

\begin{abstract}
Despite the widespread use of the term "mainstream," it is not easy to qualify the concept in empirical terms. This article deals with the reasons for this difficulty. Based on cultural studies, the article develops a concept of mainstream youth culture by mapping relations between mainstream and youth culture as found in analyses of classical works on subcultures (CCCS) and club cultures (MIPS). As an effect of opposite theoretical perspectives (structural and cultural), there is neither clarification nor consensus in defining what or who is in the mainstream. There is a gulf between the structural perspective in conceptualizing youth as a subculture opposed to the mainstream dominant (middle class) adult culture, and the cultural perspective which sees youth as belonging to club culture formations in order to distinguish them from the mainstream pop culture. One approach is not more effective than the other. The article introduces a theoretical concept of mainstream youth culture by bringing together both the structural and cultural perspectives. From this perspective the mainstream can no longer be seen as unified or monolithically "Other". Rather, mainstream youth culture is conceptualized as a space where practices of social and cultural differentiation unfold.
\end{abstract}

KEY WORDS Club cultures, dominant culture, mainstream, popular culture, subcultures, youth

\section{Úvod}

Období po druhé světové válce s sebou přineslo pluralitu výrazných hudebních a tanečních forem, módních stylů a způsobů, jak trávit volný čas. Uvedené praktiky a významy spojené s mladými lidmi získaly souhrnné označení kultura mládeže (Barker 2006, Muggleton 2005). Kultura mládeže zaujala významnou pozici v oblasti kulturálních studií a nastolila řadu důležitých témat - mezi nejdiskutovanější patřila především problematika kulturní klasifikace mládeže ${ }^{1}$ jako sociální kategorie, dále vymezení třídy, rasy a genderu, role a funkcí médií, otázky prostoru, vkusu, spotřeby, stylu a významů. Jelikož kulturální studia považovala rezistenci za specifický atribut související s etapou mládí, byla zvláštní pozornost soustředěna také na otázku rezistence (rebelie) mládeže, zejména ve vztahu k dominantní kultuře.

Sociální studia. Fakulta sociálních studií Masarykovy univerzity, 1-2/2007. S. 235-248. ISSN 1214-813X.

1 Kategorie mládeže není biologickou univerzálií, ale měnícím se sociálním a kulturním konstruktem, který se objevil v určitém čase a za určitých okolností, zejména díky prodloužení doby studia vyvolanému poptávkou po mladé a zároveň kvalifikované pracovní síle. Díky této strukturální změně, jež zlepšila ekonomické podmínky mladých lidí, vzniká prostor volného času a trh orientovaný na mládež (Muggleton 2005: 205-207). 
Empirické výzkumy v oblasti sociologie mládeže vycházely až doposud převážně ze dvou teoretických perspektiv - kulturální a strukturalistické. Oba prrístupy jsou spjaty s tradicí fungování Centra pro současná kulturální studia (CCCS), založeného v 60. letech na půdě Birminghamské university. ${ }^{2}$ CCCS svým subkulturním pojetím mládeže významně ovlivnilo bádání v oblastech kulturálních studií, kriminologie, sociologie mládeže a minorit, antropologie hudby a teorie kultury a spotřeby. Současní kritici teorie subkultur však namítají, že výklad stojící na binárních opozicích hlavní proud (mainstream) - subkultura, rezistence podrobení se, dominantní - podřízený je v dnešní době neudržitelný (Barker 2006). Podobný názor vycházel také z řad mladých výzkumníků působících v CCCS. Vnitřní rozpor vyvrcholil v první polovině 90 . let, kdy se na půdě Manchesterského institutu populární kultury (MIPC) etablovala nová vědecká disciplína. Takzvaná populární kulturální studia (Popular Cultural Studies) přišla s novým konceptem klubové kultury. ${ }^{4} \mathrm{~V}$ centru jejich zájmu stála populární hudba, klubování (clubbing) a globální formace mládeže, jež podle MIPC nahrazují uzavřené subkultury. Přes konceptuální rozpor sdílely tyto dva vědecké ústavy do jisté míry shodnou metodu analýzy: kategorie mladých lidí, kterými se v rámci svých studií zabývaly, zkoumaly v opozici k mainstreamu.

\section{Koncept mainstreamové kultury mládeže}

Obecně však mainstreamová kultura mládeže stála mimo systematický akademický výzkum obou škol. Dick Hebdige (1979), představitel CCCS, a Sarah Thornton (1996) a Andy Bennett (1999) z MIPC se tímto tématem zabývají jako jedni z mála. Na základě několika vybraných textů těchto autorů a autorky budeme moci porovnat odlišné pojetí kon-

2 Centrum pro současná kulturální studia (CCCS) není jedinou institucí, která využívala při výzkumech mládeže subkulturálního pojetí. Subkulturální teorie se postupně vyvíjela od poloviny 60 . let 20. století a dá se rozdělit podle čtyř základních př́stupů. Jenks (2005) používá Brakeovu (1985) taxonomii: 1. raná sociální ekologie zkoumající čtvrtě dělnické třídy, navazující na sociologii města v tradici Chicagské školy; 2. sociologie vzdělání a delikventních subkultur zkoumající vztah volného času, zábavy a kultur mladých; 3. současná teorie deviace a sociální reakce navazující na ranou sociální ekologii; 4. přístup CCCS využivající při studiích kultur mládeže a jejich stylů marxistického rámce (Jenks 2005: 15).

3 Subkultura mládeže je typ subkultury vázaný na specifické chování mládeže, na její sklon k určitým hodnotovým preferencím, akceptování či zavrhování určitých norem, životní styl odrážející podmínky života. Subkulturu mládeže lze smysluplně vymezit a pochopit pouze ve srovnání s hodnotami, chováním a životním způsobem dospělých v jedné a téže společnosti. Většinou se předpokládá, že subkultura mládeže vzniká tam, kde se historicky a situačně zvýrazní odlišnosti životní filozofie a životního stylu mladých natolik, že vytvoří specifický kulturní vzor chování (Velký sociologický slovník 1996: 1248).

$4 \quad$ Teoretici z MIPC se zabývali dopadem regulace zákonů na britskou kulturu mládeže v 80 . a 90. letech 20. století. Za prvé tím, do jaké míry tato zákonná opatření kulminovala v eventuální kriminalizaci určitých druhů hudby, za druhé pak tím, jak tato stigmatizace vyústila ve vytváření nové, tzv. klubové kultury (Redhead 1997: xi). 
ceptu mainstreamové kultury, způsobené rozdílným zaměřením strukturalistického a kulturálního př́stupu. ${ }^{5}$

Dick Hebdige (1979) zavádí ve své práci Subculture: The Meaning of Style dva stěžejní pojmy - styl a brikoláž. Stylem nazývá označující praktiku subkultur mladých, včetně převádění významových kódů získaných přeměnou zboží na kulturní znaky. K přenosu dochází skrze aktivní brikoláž, čili juxtapozici původně nesouvisejících označujících objektů, jež jsou pořádány tak, aby vytvárely nový význam v neotřelém kontextu (Barker 2006). Hebdige vnímá styl a brikoláž jako vyjádření symbolické rezistence subkultur mladých proti mainstreamové dominantní kultuře dospělých. Sarah Thornton (1996) analyzuje klubovou kulturu vymezenou viči mainstreamu pomocí konceptu subkulturního kapitálu. V knize Club Cultures: Music, Media and Subcultural Capital popisuje subkulturní kapitál jako záležitost vkusu (především v oblasti hudby a módy). Mainstream nedefinuje jako prostor charakteristický absencí mládeže, ale dominancí populární kultury, jež vytlačila autenticitu a kulturní vkus. Andy Bennett (1999) zachycuje optikou neo-tribalismu hybriditu a fluiditu městské klubové hudební scény, kterou vymezuje v opozici k mainstreamové populární hudební kultuře. Ve studii Subcultures or Neo-tribes? Rethinking the Relationship between Youth, Style and Musical Taste posouvá vztah mládeže $\mathrm{k}$ hudebnímu vkusu a stylu ještě dál do oblasti experimentování. Jednotu mezi konkrétní hudbou a konkrétním stylem (například stylem oblékání) popisuje oproti Sarah Thornton jako méně fixní a naopak zvýrazňuje stylovou hybriditu. Zatímco strukturalisté se soustředí na témata nezaměstnanosti, na problematiku bydlení a vzdělávání, kulturalisté se zabývají primárně otázkami subkulturních stylů, klubových kultur a hudby.

Steven Miles ${ }^{6}$ upozorňuje, že kulturální a strukturalistický přístup nelze oddělit, jelikož oba reflektují konstrukci identity mladého člověka. „Jistěže existuje rozdíl mezi kulturními a strukturálními aspekty $\mathrm{v}$ životech mladých lidí. Ale tento rozdíl existuje spíše $\mathrm{v}$ myslích a metodách sociálních vědců než v samotných životech mladých lidí“ (Miles 2003: 171). S odkazem na Jonese a Wallaceho (1992) hovoří o mnoha autorech, kteří k mládeži přistupují jako k barometru sociální změny či indexu sociálních „nemocí“. Tento melodramatický kontext polarizoval témata výzkumu mládeže bud' $\mathrm{v}$ rámci extrémních subkultur či klubových kultur, nebo se soustředil na tzv. strukturálně „znevýhodněnou“ mládež jako na obět’ nezaměstnanosti, závislosti na drogách či alkoholu (Jones a Wallace 1992, in Miles 2000). Miles vystihuje tendenci posuzovat celek dle jeho částí kritikou témat, na něž se sociologie mládeže doposud soustředila. Podle něj tím eliminovala onen celek, který sám nazývá „mainstreamovou mládeži“ (mainstream youth) (Miles 2000: 3). S důrazem na význam společenské změny přehodnocuje dosavadní prř́stupy zkoumající britskou mládež. Miles však nezůstává

5 Zatímco Dick Hebdige popisuje dominantní mainstreamovou kulturu jako symbol rodičovské generace, Sarah Thornton a Andy Bennett zahrnují do dominantní mainstreamové kultury také mládež. Thornton, Bennett i Hebdige v podstatě píší o generačním konfliktu. Zatímco Hebdige jej vidí v inter-generační rovině, Thornton a Bennett jej zkoumají v rovině intra-generační.

6 Steven Miles působí jako docent sociologie na University of Plymouth. Ve svých výzkumech se zabývá otázkou, co znamená být $\mathrm{v}$ dnešní době mladým člověkem. Zasazením identity současného mladého člověka do konceptuálního rámce spotřeby vypracoval systematickou kritiku tradičních př́stupů výzkumů mladých lidí a jejich přechodu do dospělosti. 
pouze u kritiky a navrhuje řešení. Spotřeba je podle něj prostorem, který nabízí možnost propojení kulturální a strukturalistické (strukturální) perspektivy, nebot' kulturní praktiky konzumerismu aktivně reflektují strukturální zkušenost mladých lidí, se kterou se tito dennodenně potýkají. Znamená to, že míra, v jaké si mohou dovolit konzumovat (nákup oblečení, chození do klubů etc.), je závislá na strukturálních podmínkách, které je obklopují. Ačkoliv Miles (2000) na několika místech své knihy Youth Lifestyles in a Changing World upozorňuje na nutnost přenést pozornost na mainstreamovou mládež, sám ji jako kategorii nikde nedefinuje. Milesova vize vyžaduje překonání hranice mezi strukturalistickým a kulturálním př́stupem. Vybízí tímto ke zkoumání otázek autenticity, heterogenity, homogenity, rezistence i pasivity ze zcela nového pohledu. V tomto smyslu jsou Hebdigeova brikoláž a styl, subkulturní kapitál Sarah Thornton a neotribální formace a stylová hybridita Andy Bennetta stále aktuálními pojmy. Z Milesovy slučující perspektivy je lze považovat za součást vzorců hodnot, postojů a jednání charakteristických pro mainstreamovou kulturu, jejíž součástí jsou také mladí lidé.

\section{Mainstream}

V té nejobecnější rovině vyjadřuje mainstream „Všeobecný, společně sdílený proud myšlení, hodnot a norem přijímaný majoritní společností“ (Longman Family Dictionary 1991: 415). Myšlení je v tomto kontextu chápáno jako společný názor či mínění odkazující na podobné koncepty a procesy zahrnující poznávání, cítění, vědomí, ideje a imaginaci. Mainstream je pak chápán jako synonymum normality a normálnosti, jako něco, co je běžné a typické, jako střední cesta, konvenčnost a majorita. Výraz mainstream je nejčastěji užíván ve spojení s uměním (mainstreamová hudba, mainstreamová literatura, mainstreamová móda, mainstreamová produkce). Takto pojatý mainstream zahrnuje:

- něco, co je běžné, obvyklé a normální - normální v tom nejširším slova smyslu, to znamená signifikantně se neodlišující od majority;

- něco, co je známé (všední) masám;

- něco, co je dostupné široké veřejnosti.

Mainstream je nejčastěji spojován s populární kulturou, typicky šířenou masovými médii. V opozici k mainstreamu pak stojí subkultury, protestní kultury, kulty, undergroundová kultura a některé literární žánry. Mainstream lze chápat také jako synonymum konformity. Např́klad vrstevnická, profesní či jinak vymezená skupina působí skrze různé druhy jednání, a činnosti jako nátlakové prostředí. Konformita s normami a zvyky či poslušnost pravidlům a zákonům skupiny fungují jako prostředek inkluze pro ty, pro něž je členství v dané skupině důležité. $Z$ tohoto důvodu je $\mathrm{v}$ širokém povědomí mainstream vnímán jako antiteze individuality se silně pejorativním podtextem. ${ }^{7} \mathrm{~V}$ hovorové řeči mladých lidí se ustálilo slovo „sheeple“, jakási varianta českému spojení „stádní lidé“ slučující anglická slova sheep (ovce) a people (lidé). Není však uživání slova mainstream pro označení davu bez vlastního názoru a vkusu př́liš zjednodušující?

Dosavadní př́stupy zkoumaly různé kategorie mladých $\mathrm{v}$ opozici $\mathrm{k}$ mainstreamu. Předpoklad, že mládež stojí mimo hlavní proud, zploštil toto téma na jednoduchou rovnici

$7 \quad$ Viz http://en.wikipedia.org/wiki/Mainstream 
my vs. oni; přičemž „my“ symbolizuje kreativitu a heterogenitu kultury mládeže stojící mimo hlavní proud, zatímco „oni“ představuje homogenitu dominantní kultury a konformitu světa dospělých.

Ve skutečnosti mainstream představuje multidimenzionální prostor, který kreativitu, konformitu, homogenitu, heterogenitu i prvky dominantní kultury a subkultur nestaví do opozice my vs. oni, ale navzájem je kombinuje. První kombinace odkazuje k tomu, že se jedná o mezigeneračně sdílený prostor, druhá se týká synchronizace homogenity a heterogenity a třetí kombinace se vztahuje $\mathrm{k}$ paralelnímu posilování konformity a kreativity.

Mainstream je prostor sdílený generacemi. Tento první způsob nahlížení je postaven na předpokladu, že mainstream (jakožto soubor hodnot, norem a názorů přijatých většinou) je uchováván v generačním přenosu, a tak zajištuje relativní stabilitu a trvání společnosti. Subkulturní teorie líčí postoj mládeže k dominantní ideologii (rodičovské generaci) jako silně opoziční. Opomíjí tímto základní charakteristiku jakékoliv society - a to její sebezáchovný pud artikulovaný nadějí přítomné $\mathrm{v}$ generačním přenosu základních hodnot, norem a myšlení. Subkulturální př́istup vyvolává dojem, že být mladý musí nutně znamenat bouřit se, rebelovat, jít proti hlavnímu proudu. Např́íklad Matza (1962) usuzuje, že rebelie je př́mo esencí mládí, projevující se ve třech atraktivních formách: delikvenci, radikalismu a bohémství (Matza 1962 in Brake 1985: 22). ${ }^{8}$ Matza si však nevšímá rozdílné intenzity, s jakou mladí k rebelii přistupují. Berger (1963b), další ze subkulturálních teoretiků, již připouští existenci mladých, dospívajících osob bez větších známek revolty. Mírná rebelie se u nich projevuje nanejvýš módními výstřelky, ne však „deviantním“ životním stylem. I tuto skupinu považuje za subkulturu a označuje ji za tzv. „respectable youth“, poslušnou mládež, která je deviantními subkulturami nahližžna jako negativní referenční kategorie, jako konformisté, slušňáci, tzv. „straights“ (Berger 1963b, in Brake 1985: 23). Nerevoltující mládež tedy v subkulturální teorii působila jisté metodologické potíže. Jakoby si teoretici nepřipouštěli, že by mainstream mohl představovat prostor, jenž generace názorově nejen odděluje, ale také spojuje. Zvláště pokud si uvědomíme, že mainstreamové hodnoty dominantní ideologie jsou obsaženy nejen ve formálních institucích, ale především v těch neformálních, jako jsou rodina, jazyk, vzdělání, obecně řečeno v kulturní tradici. Subkulturální pojetí však evokuje představu jejich odmítnutí a nahrazení hodnotami odlišnými. V konceptu zůstává zcela netematizována ta kategorie mládeže, $\mathrm{z}$ níž by se rekrutovali př́islušníci následující mainstreamové dospělé kultury. Otázkou tedy zůstává, jak vysvětlit vznik budoucí dominantní mainstreamové kultury dospělých ve společnosti, ve které se předpokládá, že něco jako mainstreamová mládež zcela chybí.

Druhá kombinace, zahrnující vnitřní homogenitu a zdánlivou vnější heterogenitu, úzce souvisí s paralelním posilováním konformity a kreativity, tj. $\mathrm{s}$ obsahem kombinace třetí.

8 Vedle delikventní mládeže a kulturních rebelů (bohémská tradice) se Matza zabýval především politicky militantní mládeží, u níž se rebelie projevovala politickou aktivitou s širokým rozsahem - od environmentální a veřejné politiky k př́mé militantní akci. Jednalo se o vzpoury, politické skupiny nebo široká masová hnutí (mírová hnutí 50. let), etnické skupiny (Young Lords nebo Black Panthers), hnutí za občanská práva, tematicky zaměřené skupiny protestující proti válce ve Vietnamu, pacifisty, studentské skupiny, politické strany a environmentalisty. 
Post-subkulturální perspektiva zbavila mainstream jeho ideologické dimenze a označila jej za synonymum populární kultury. Aby se vypořádala se způsoby sdružování mladých, jež neodpovídaly znakům subkultury, a zároveň se vyhnula užívání označení subkultura, zavádí pojmy clubcultures a neotribes. Analyticky se tak snaží zachytit fluiditu a hybriditu současné (převážně městské) klubové scény, symbolizující různorodost kulturních vkusů mládeže. Mainstream je tedy považován za cosi jednolitého bez nádechu kreativity. Paradoxně klubová kultura a novodobé kmeny analyzované teoretiky z MIPS jako alternativy k neautentické pop kultuře jsou současně popisem kreativity mainstreamové kultury mládeže. Kulturní dimenze mainstreamu je postavena na zdánlivém popření přináležitosti k němu. Toto zdánlivé popření otvírá prostor pro ty mladé, kteří svou touhu po odlišení ventilují v širokém spektru módních a hudebních stylů často inspirovaných subkulturami, které svou image a hudbou vyjadřovaly odstup od hodnot většinové kultury. Projevem rebelie mainstreamové mládeže je experimentování s oblečením, účesy a poslechem jak populární, tak alternativní hudby. Je to kultura obývaná brikoléry, jejichž hodnoty jsou však, na rozdíl od subkultur, v relativním souladu s dominantní kulturou. Jednou nohou jsou tak tito mladí lidé v harmonii s dominantními hodnotami, druhou nohou stojí ve světě kulturní pestrosti, jehož krédo zní: chci být rozeznatelný od ostatních; čili o to, být viděn jako jedinečný, neusiluji jen já, ale také ostatní.

Kreativní element mainstreamové kultury umožňuje pohrávání si s vlastní identitou a současně tímto způsobem ventiluje potenciální přemíru mladistvé rebelie. Konformita funguje jako obranný mechanismus sloužící k uchování řádu a stability, nutných k dalšímu generačnímu přenosu. Stylová pestrost současné mládeže je často mylně interpretována jako subkulturní heterogenita. Ve skutečnosti se často jedná o mainstreamovou kulturu mladých „hrající si“ na subkultury. „Měním se z hodného kluka v modrých džínech a košili v punkového rockera. Záleží na tom, jak se cítím,“ cituje Miles z výzkumu Johanssona a Miegela (1992, in Miles 2000: 32). Ilustruje tím silnou vazbu mezi autenticitou a vnitřními pocity. Následující kapitola se blíže zabývá proměnou obsahů konceptu mainstreamu a shrnuje kritiku spojenou s interpretací jeho významů.

\section{CCCS - Mainstream jako symbol dominantní kultury dospělých}

Centrum pro současná kulturální studia (CCCS) bylo původně zamýšleno jako intelektuální projekt postgraduálního vzdělávání. Pod vedením Stuarta Halla (1968-1979) došlo ovšem ke zformování svébytné a jasně definované oblasti nazvané kulturální studia. Původně se CCCS zaměřovalo na ,žitou“ kulturu s důrazem na kulturní odlišnosti jednotlivých tříd. Orientace na kulturalismus byla později překonána strukturalismem, zvláště jeho marxistickým pojetím. Rozhodující vliv zde sehrála díla Barthese, Althussera a zejména Gramsciho. ${ }^{9}$ Klíčovými pojmy se staly text, ideologie a hegemonie, zkoumané skrze populární kulturu.

9 Gramsciho vliv pramení z vytvoření neredukcionistického marxismu. Gramsci chápal významy a ideje jako vývojové síly, které nelze vysvětlit z čistě ekonomického hlediska, a proto bylo také jeho dílo významné pro západní marxisty typu Stuarta Halla, kteří se zajímali o kulturu (Barker 2006: 61). 
Výzkumná témata se týkala subkultur mládeže, masových médií, vzdělávání a výchovy, otázek genderu a autoritářského státu (Barker 2006).

CCCS se primárně zabývalo analytickým konceptem subkultur, vnímaným jako stylizovaná forma rezistence mládeže proti moci. ${ }^{10}$ „Subkultury mládeže se z této perspektivy vyznačují rozvojem specifických stylů, což je pokládáno za dobytí ,vlastního prostoru“ a oddělení od rodičovské i tř́́dně hegemonní kultury. Děje se tak cestou symbolického rozkladu trrídních kontradikcí, s nimiž se mládež setkává“ (Barker 2006: 97). Romantické pojetí interpretovalo poválečné subkultury teddy boys, mods, skinheads a punkerů s důrazem na individualitu a třídně založenou homologii jako na způsob, skrze nějž se mládež z dělnické třídy bránila dominantním hegemonním institucím britské společnosti (Jenks 2005). Subkultury byly označeny za rebelantsky „politické“, se schopností rituálně vzdorovat kapitalistickému začlenění. CCCS tuto rebelii považovalo za „magické“ ‘ řšení společenské podř́zenosti (Muggleton a Weinzierl 2003).

Dick Hebdige (1979) zkoumal s využitím sémiotiky styl spektákulárních subkultur britské mládeže 70. let. „Styl je podle Hebdige označující praktika, která může fungovat jako sémiotická rezistence proti dominantnímu rádu“ (Barker 2006: 65). Hebdige považoval britský punk za revoltující styl, vyjádřený skrze na první pohled chaotický vzhled, který však obsahoval vnitřní logiku a pravidla. Punkeři se oblékali do všemožné veteše, fetišistických obleků z plastů, do školních blejzrů, opotřebované armádní výzbroje, barvili si vlasy, zuby i obličej. Podivný vzhled doprovázený nihilistickým pohledem na budoucnost byl výrazem protestu. Styl subkultury skinheads zase svými krátkými vlasy, těžkými botami a kšandami sehrával roli v imaginárním znovudosažení „tvrdosti““ muže dělnické tř́́dy. Tato móda byla chápana jako brikoláž: šle, hudba ska, krátké vlasy a těžké boty měly symbolizovat drsnost dělnické maskulinity (Barker 2006: 29, 184-185).

Hebdige kromě punkerů a skinheads analyzuje také styly mods a teds. Mods (zkratka pro modernisty) paradoxně spíše vyvrací pojetí subkultury rozvíjené v rámci CCCS, zejména zdůrazněním vazby k mainstreamové kultuře mladých 60 . let, která se jimi inspirovala. Mods se vynořili v kavárnách a jazzových klubech Londýna. Vyznávali minimalismus, nosili perfektně padnoucí obleky a vlasy hladce sestř́hané podle slavného kadeřníka Vidala Sassoona. Mods nepocházeli jen z dělnických rodin, ale zejména ze střední vrstvy, původem však opovrhovali, nezáleželo jim na tom, odkud kdo pochází, ale na tom, kam ve své budoucnosti směřuje. Mods nebyli subkulturou, jež by vyjadřovala odpor vůči generaci svých rodičů. Ve skutečnosti byl styl, se kterým přišli, zaměřen proti o něco málo starší subkultuře z konce 50. let - starosvětským teddy boys (Máchalová 2002). Hebdige (1988) poukazuje na to,

10 Subkulturální přístup nebyl ušetřen kritiky zaměřené na opomíjení jednotlivých lokálních variací stylů i hudby a nezohlednění geografických zvláštností subkultur mládeže. S tím souvisí i skutečnost, že CCCS vytvořila britský model, který byl vypracován s ohledem na velice specifickou část mládeže - na bílé muže z dělnické třídy, což jen obtížně umožňovalo jeho aplikaci v jiném než britském kontextu. Muggleton a Weinzierl (2003) kritizují to, že současné kultury mládeže jsou charakterizovány mnohem komplexnější stratifikací, než s jakou pracovali teoretici z CCCS, vymezenou jako jednoduchá dichotomie „monolitický mainstream - rezistentní subkultury“ (Muggleton a Weinzierl 2003: 7). Jde o důležitý poznatek, který mimo jiné definuje mainstream v dlouhodobé tradici CCCS jako oblast spojovanou jednak s dominantní ideologií, jednak s rodičovskou generací. 
jak mods s využitím mainstreamových objektů definovali svůj vlastní styl. Vzhled mods byl mezinárodní. Nosili italské obleky s krátkými kalhotami a saky, špičaté boty, čistě bílé košile. To vše nakupovali na Carnaby Street. Jezdili na skútrech značky Vespa nebo Lambretta. Modernisté si jako součást svého stylu vybrali produkt (italské skútry) určený primárně ženám a transformovali jej do symbolu mladistvé prudkosti. Nebránili se ani populární kultuře a využili masových médií, aby si sami vedli vysílání svých oblíbených hudebních interpretů. V pořadu Ready, Steady, Go! $!^{11}$ se objevili Beatles, Rufus Thomas, Aretha Franklin nebo The Who. Medializace akcelerovala oblíbenost a následné kopírování jejich stylu britskou mládeží. Elegantní „smart“ styl se tak stal komoditou mainstreamové kultury mladých (Osgerby 1998 in Miles 2000). Koncem 60. let mods mizí ze scény, ožívají opět až v souvislosti s acid jazzem a znovuobjevením modernistické tradice. Hudební styl acid je pak spojován se zrodem klubové kultury mládeže, které se věnovali teoretici z MIPC.

\section{MIPC - mainstream jako symbol populární kultury}

Hebdigeovi kritici z řad MIPC tvrdí, že $\mathrm{v}$ jeho interpretaci stylu převládla rezistence, a naopak rezistence se zredukovala na záležitost stylu. Styl tak podle nich přišel o složky zábavy a byl minimalizován na otázku politiky. Zatímco většina populárních diskurzů byla zarámována do konceptu teenagera, CCCS nikdy nezkoumala mládež, která subkulturní role převzala z pouhé zábavy nebo na základě touhy „být chvíli in, cool a trendy“. Frith (1983, in Bennett a Kahn-Harris 2004) si všiml faktu, že většina dospívajících pocházejících z dělnické trrídy často prošla více subkulturními skupinami, změnila identitu a více než o skutečné dlouhodobé členství se jim spíše jednalo o hru na subkulturní členství. ${ }^{12}$ Stejně tak teoretici z CCCS prŕliš nezohledňovali vliv pohlaví, povolání a rodiny na př́slušnost k určitým subkulturám. Steve Redhead, ${ }^{13}$ David Muggleton a další přestavitelé kulturálního př́stupu shledali strukturalistické ukotvení konceptu subkultur problematickým, jelikož toto vymezování mládeže selhávalo ve vysvětlení vztahů mezi styly, hudebními žánry a identitou. Identitu charakterizovali jako flexibilnější, a proto svi̊j výzkum zarámovali do konceptu klubové kultury mládeže, která více vyhovovala pestrosti jednotlivých stylů a proudů (Bennett a Kahn-Harris 2004). I ostatní teoretici spojovaní s post-subkulturním př́stupem se zaměřují na vzrůstající pružnost členství v kulturách mládeže a pokouší se vytvořit analytické rámce $\mathrm{k}$ vysvětlení typického seskupování mládeže. Autorkou, jež zpochybňuje Hebdigeovu koncepci opo-

11 Viz http://www.modculture.co.uk/culture/culture.php?id=22

12 Berger (1963b) podotýká, že subkulturní formace jsou zvláště atraktivní pro střední třídu. Jejich poutavost je způsobena přsunem k mládí jako filozofii umožňující odpoutání se od skutečného biologického věku. Jedná se o mladý a čerstvý pohled na svět, který nemusí být nutně rebelský. Střední třída si díky lepší ekonomické pozici může dovolit přebírat životní styl mládí skrze spotřební vzorce. Podle Bergera naopak u dělnické třídy vstup do manželství a sféry práce znamená konec rebelské aktivity mladých. Emocionální element naplňovaný skrze dočasné členství v subkultuře vrstevníků přebírá manželství (Brake 1980: 22).

13 Redhead tento fakt dokládá na jednotlivých hudebních směrech taneční hudby z pozice postmoderní kritiky CCCS. 
zic avantgardní - buržoazní, podřízený - dominantní, subkulturní - mainstreamový, je Sarah Thornton.

Sarah Thornton (1996) opouští ortodoxní Gramsciho model. Svůj argument staví na neefektivnosti tří hlavních dichotomií, které se ujaly v akademickém diskurzu „mainstream kontra alternativy“: 1 . Dominantní kultura, buržoazní ideologie versus subkultury a deviantní skupiny; 2. masová kultura, reklamní ideologie versus studentská kultura a vzdělaná avantgarda; 3 . dominantní kultura, buržoazní ideologie versus studentská kultura a vzdělaná avantgarda. Poukazuje na to, že všechny tyto opozice jsou neúčinné při odhalování jemných nuancí subkulturního členství. Již dříve užívaný protiklad „hip versus mainstream“ převádí na rovinu ,pop versus ostatní hudební styly“, které označuje za klubovou kulturu. Klubovou kulturu popisuje jako „kulturu vkusu“ založenou na sdílené vytříbenosti, především v hudbě. Thornton odlišuje klubovou kulturu mladých (medializovanou jako subkultury) od mainstreamové populární kultury mladých na základě kritéria autenticity. Rozeznává skrytý elitismus a separatismus odhalující podobnosti a rozdíly mezi uměním a undergroundovými subkulturami. Klubovou kulturu i umělecký svět klade proti masové kultuře, ${ }^{14}$ ale zatímco se umělci obávají trickle down efektu ${ }^{15}$, podle Sarah Thornton ${ }^{16}$ představuje skutečnou hrozbu pro undergroundové subkultury popularita a proměna $\mathrm{v}$ mainstreamovou pop hitparádu, tedy ztráta autenticity. Zde autorka zavádí pojem sociální logiky subkulturního kapitálu, v němž hrají klíčovou roli koncept třídy a teorie kapitálů Pierra Bourdieu (1998). Klubová kultura znamená, že různé vzorce hudební spotřeby jsou propojeny se společným hudebním vkusem. Ve skutečnosti jsou navíc svázány s obecnými zásadami dílčích klubů a jeho návštěvníků - kluberů (clubbers), jejichž hudební vkus Thornton zarámovala do konceptu subkulturního kapitálu. Pro klubové kultury tak znamená obrana před komercializací nejen úsilí zachovat si jedinečnost a původnost, ale v podstatě snahu přežít. Média dokáží klubové kultury zpopularizovat natolik, že se postupně stávají obchodním artiklem. Tím, že inspirují módu a hlavně populární hudební průmysl, jsme často svědky toho, že na ulicích, v klubech a ve školách potkáváme mnoho mladých lidí vykazujících navenek prvky subkulturního členství. At' se již jedná o účesy, líčení nebo oblečení, je zajímavé, že přes všechnu pestrost vždy jeden styl převládá, časem však ustupuje a je nahrazen stylem jiným. Mainstream sym-

14 Masová a populární kultura nejsou synonyma. Obecně lze říci, že kritikové, kteří zdůrazňují výrobní aspekt kultury používají výraz „masová kultura“. Ti, kteří zdůrazňují proces spotřeby, užívají výraz „populární kultura“ (Barker 2006: 113).

15 Georg Simmel (1997) v eseji O módě popisuje imitování módy. Později byl tento proces napodobování definován jako trickle-down effect - teorie módní difúze. Módní styl vyšší třídy je imitován třídou nižší, cena odpovídající tomuto stylu klesá. Prošel-li styl sociální strukturou odshora až dolů, móda se musela změnit, protože v sociální struktuře došlo v tomto okamžiku ke zdánlivé univerzalizaci jednoho ze statusových symbolů, který diferencoval sociální vrstvy. Ztráta exkluzivity si vyžadovala novou stylovou změnu a nový symbol. Trickle down effect je periodický, protože sociální systém stále hledá symboly, které odlišují vyšší vrstvy od nižších, a naopak symboly, které přibliží nižší vrstvy vyšším.

16 Thornton se ve svém etnografickém výzkumu zabývá britskou klubovou kulturou ravers (19881992). Její cílovou skupinu tak tvoří především „bílá“ mládež střední třídy ve věku 14-22 let. 
bolizuje proud (stream) ${ }^{17}$; jeho podstatou je tedy dynamika a pomíjivá náklonnost. Tento fakt spíše než o subkulturním rozšíření svědčí o existenci mainstreamové kultury mládeže, která v pravidelných intervalech přebírá různé prvky těch subkultur, jimiž se momentálně inspiruje či obdivuje.

Autenticita je tedy způsobem, kterým klubové kultury samy sebe odlišují od mainstreamové kultury. Sarah Thornton tento způsob diferenciace pozorovala nejvýrazněji prostřednictvím hudby. I klubová kultura, jak ji líčí autorka, je, co do množství hudebních stylů, velmi různorodá. Pocit exkluzivity z ní však tvoří jednotnou kulturu. Subkulturní kapitál je způsobem, jímž klubová taneční hudba vymezuje sama sebe vůči mainstreamovému hudebnímu vkusu a posluchačům mainstreamové hudby mimo klub. Exkluzivita je přenášena př́itomností dýdžejů, kteří zprostředkovávají autentický zážitek prímo na místě skrze mixování hudby. V očích kluberů se tedy jedná vždy o originál, který neztrácí svou auru ${ }^{18}$. Mainstream pak tvoří sít' obchodů s hudební CD produkcí, rádiové stanice a jejich konzumenti, tedy ti, kteří přicházejí o komplexitu hudby a zážitku v prostředí klubu. Uvedený koncept souvisí s mediální konstrukcí subkulturní rebelie. Thornton argumentuje, že klubová kultura se stává politicky relevantní pouze tehdy, když je jako taková mediálně zarámována. Jinými slovy, škodlivá a hanlivá mediální reportáž není verdiktem, ale esencí rezistence klubové kultury (Thornton 1996: 137). Ačkoliv si je tato autorka vědoma propojení médií s dominantní ideologií, na média pohlíží primárně jako na nástroj mainstreamové, tedy populární kultury. Vztah médií a klubové kultury redefinuje jako spolupráci. Cílem této kooperace je získat si nelibost médií. Mediální nesouhlas je mechanismem, díky němuž tyto kultury vkusu získávají nálepku „subkultury“. Proces mediálního vytváření subkulturní identity začíná již na mikro úrovni, jako jsou tištěné letáčky a pamfletky. To, čeho se klubová kultura obává, není morální panika ani zákony, ale mediální požehnání. Pozitivní medializace určitého hudebního vkusu znamená konec subkultury, tedy inkorporaci do mainstreamu populární kultury. Role mediální reprezentace znovu otevřela diskuzi na téma mainstreamové/nemainstreamové kultury mladých. $Z$ tohoto pohledu nejsou subkultury ničím jiným než mediálním konstruktem, který mladí lidí zpětně vnímají jako pravý. Thornton takto upozornila na další nedostatek subkulturní teorie, a to na neadekvátnost užívání subkultury jakožto validního a objektivního sociologického konceptu.

Také alternativní teoretický model Andy Bennetta (1999) je kritikou validity subkulturního rámce. Jeho první námitka se týká problematické objektivity, druhá obtížnosti při

17 Pro slovo proud angličtina uživá kromě slova „stream“ také výraz „current“. Oba výrazy lze přeložit jako obvyklý, běžný, současný, aktuální (ve smyslu živý a momentálně zajímavý). Stejně tak, když použiváme výraz mainstream k označení dominantního proudu norem, hodnot, myšlení i kulturních praktik, prijímaných majoritou společnosti, nesmíme zapomenout, že mainstream je dynamický a proměnlivý.

18 Walter Benjamin (1979) označoval aurou vztah pocitu k estetickému zážitku. Termín aura uživá pro označování určitého pocitu či stavu evokovaného unikátními a cennými objekty, jako jsou vzácná umělecká díla či další historické relikvie. Benjamin tvrdil, že zatímco starodávné kultury dokázaly svým výtvorům vtisknout právě tuto auru unikátnosti a významnosti, současná kapitalistická společnost je na tom zcela opačně - v důsledku masové produkce a všeobecného úpadku se jakákoliv aura rozpadá a zaniká. 
verifikování sociálních kategorií, které charakterizuje jako fluidní a hybridní seskupení, dosavadním empirickým způsobem. Problematiku objektivity vztahuje k procesu mediální konstrukce subkultur popsané Sarah Thornton (1996). Bennett upozorňuje na to, že média přenesla termín subkultury do širší veřejné sféry. Inflační používání vytvořilo ze subkultury všezahrnující a zároveň nerozlišující pojem. Ve svém důsledku je pak subkulturou označena jakákoliv odlišná kolektivní praktika, jejíž jediný viditelný, avšak také relativní vztah k subkulturám je ten, že se týká mladých lidí.

Druhou námitku demonstruje Bennett na Cagleho (1995) rekonstrukci populárních subkultur. Cagleho aplikace marxistické interpretace na spektákulární skupiny glitter rock funs zahrnuje do subkultur kategorie mladých lidí s mainstreamovým stylem i hudebním vkusem (Cagle 1995, in Bennett 1999: 604-605). Cagle argumentuje tím, že subkulturní kategorizace je oprávněná, nebot' mainstreamová stylová a hudební orientace nesvědčí o absenci potenciálního kontra-hegemonního jednání. Cagleho redefinice subkultur nicméně zahrnuje všechno a zároveň nic. Akceptace paralelní existence mainstreamových a ne-mainstreamových subkultur sice rozšiřuje pozornost na mládež hlavního proudu, nicméně devalvuje samotný význam pojmu subkultura. Jaký je mezi těmito subkulturami rozdíl, jak určit tento rozdíl, je mainstreamová subkultura vůbec ještě subkulturou? Andy Bennett zcela opouští tradiční, třídně vázaný koncept fixních subkultur. Tvrdí, že identita je více konstruktem než daností, je spíše fluidní než fixní. Stejně jako Sarah Thornton se zaměřuje na současnou městskou taneční scénu mladých Britů. Etnometodologický výzkum klubového prostředí však nerealizuje pomocí konceptu klubové kultury, ale navazuje na Maffesoliho koncept novodobých kmenů. Kolektivní družení se mladých lidí s podobnou stylovou preferencí a hudebním vkusem považuje za formu fluidního postmoderního společenství. Výrazem „městská taneční hudba“ souhrnně označuje současné formy hudby ,živě“ performované dýdžejem, jako je např́íklad house nebo techno. Autenticita, o níž hovoří Thornton, dodala taneční hudbě status „serióznosti “, a tak ji oddělila od „disko hudby a mainstreamu“. Digitální technologie umožňuje dýdžejům stále více „komponovat“, než jen přehrávat. A co více, taneční hudba se stává brikoláží stylů, je to hra samplů, rytmické shody, harmonie, stylisticky rozptýlených smyček a melodických frází, které nutí (a zároveň baví) přítomné klubery hádat: „Byl to Michael Jackson?“ (Bennett 1999: 610). Bennett ve své neotribální koncepci odděluje hudební vkus od stylu. Nepopírá existenci symetrie mezi vizuální image a hudebním stylem, zdůrazňuje nicméně fakt, že jejich vzájemný vztah je mnohem méně rigidní, než se zdá. Výsledkem je nebývalá fluidita, pružnost a zároveň eklekticismus. Volnost hudebního vkusu nevázaného na vizuální image vytváří fluidní společenství neo-tribálního charakteru.

\section{Závěr a diskuze}

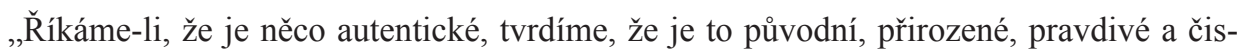
té,“ píše Barker (2006: 23). Kulturalisté i strukturalisté tvrdí, že kultury mládeže se vyznačují rozvojem stylů, jež symbolizovaly rezistenci opřenou právě o prvky původnosti a autenticity. Odlišit opoziční autentickou kulturu od mediálního a kulturního průmyslu označovaného jako mainstream je však obtížné, nebot' tato kultura je silně ovlivňována a utvářena globálním průmyslem volného času. Skeptici tvrdí, že dnešní styl zahrnuje brikoláž, tvořenou 
směsicí různých vlivů. „Jde jen o vzhled, je to zkrátka jen jiný druh módy, spíš pastiš než parodie“" (Barker 2006: 24). Mladí lidé jednají v rámci spotřeby jako brikoléri, jsou velice kreativní, vybírají si a aranžují prvky materiálního zboží a smysluplných znaků a takto konstruují mnohonásobné identity. Navzdory rozšíření tradičního subkulturního rámce o alternativní koncepty klubové kultury a neo-tribálního sdružování představuje vnitřní rozmanitost kategorie mládeže stále analytický oříšek. Slovy Barkera: „Mládež vytvořila diskurzy ,problémů‘ (mládež jako problém, mládež a její problémy) a/nebo ,zábavy“ “ (Barker 2006: 97). Zatímco kritika subkulturální teorie spočívá v přehnané politizaci, teoretici z MIPC redukují výzkumy na prostor zábavy. Koncept mainstreamové kultury mládeže vyžaduje spojení strukturalistické (strukturální) a kulturální perspektivy ${ }^{19}$, protože oddělení obou př́ístupů znamená riziko zploštění. Mainstream ve skutečnosti představuje multidimenzionální prostor. Zahrnuje paralelní existenci opozičních kombinací na ideologické i kulturní rovině. Ve stejnou chvíli vykazuje znaky homogenity i heterogenity, posiluje konformitu i kreativitu. Koncepce mainstreamové kultury mládeže neznamená popření existence subkultur. Ty však přestavují životní způsob, jenž v celé šiři prožívá jen část mládeže. Pro většinu jsou subkultury pritažlivé hlavně svým vzhledem a hudbou. $\mathrm{V}$ tomto aspektu se mainstreamová kultura blíží post-subkulturnímu modelu.

Bennettova fluidní a hybridní koncepce sice zdůrazňuje svobodu volby mezi různými hudebními styly, image i módou, ale už nerozebírá strukturální překážky, ovlivňující míru realizace těchto svobodných voleb. Kreativní element mainstreamové kultury je prostředkem umožňujícím vyrovnat strukturální nerovnosti, se kterými se většina mladých lidí potkává. Je to prostor pro ty, kteří hledají způsob vyjádření své jedinečnosti, ale necítí potřebu se nijak zvlášt' radikálně vymezovat vůči dominantním hodnotám. Miles (2000) se domnívá, že mladí lidé byli vždy do jisté míry součástí dominantní mocenské struktury, zejména v rámci spotřeby. Upozorňuje, že mladí lidé jsou v běžném, každodenním životě málokdy rebely. Mnohem více jsou ochotní jednat, a také jednají, v souladu s dominantním řádem. Ochota přizpůsobit se však závisí na tom, do jaké míry jim je umožněno konstruovat svébytné významy okolo dominantního způsobu života a jak tyto specifické významy zapadnou do dominantní struktury a jsou touto strukturou prijjaty. Mainstream slouží jako aréna k realizaci těchto požadavků. Kreativita a heterogenita zároveň posilují konformitu a homogenitu. $\mathrm{Z}$ tohoto pohledu jsou mladí lidé stylově i hudebně „promiskuitní“. Tato promiskuita budí dojem zdánlivé heterogenity, interpretované jako subkulturní exploze, ve skutečnosti je to však stylová hra na sub-

19

Anglický výraz „structural“ lze přeložit jako strukturální i strukturalistický. Tyto dvě verze překladu však nejsou svým obsahem totožné. Strukturalismus je velmi široký vědecký směr i metoda v jazykovědě, literární vědě a jiných humanitních vědách, který vznikl ve 20. století. Saussure rozlišil jazykový systém language (tj. znalost jazyka) a jazykového chování parole (tj. použití této schopnosti k řeči). Jazyk chápe jako systém znaků, který je ve vztahu k lidské zkušenosti jako k označovanému. Oproti analytické metodě rozkladu a studia jednoduchých prvků zdůrazňuje význam struktur, tj. celkového uspořádání složitých systémů a vztahů mezi jejich prvky. Toto rozlišení se pak velice osvědčilo i v řadě dalších oblastí. Příkladem je klasické dílo Dicka Hebdige (1979) Subculture: The Meaning of Style. Hebdige využívá strukturalistické metody v odhalování významů, skrytých ve stylech oblékání punkerů, mods, teds a skinheadů, jako výrazu nesouhlasu se sociální strukturou. 
kulturní členství. Podstata rebelství nespočívá v tričku s nápisem „rebel“, punkera nedělá jeho účes nebo cvoky na bundě a jednorázová účast na letní techno párty neznamená, že se z člověka stal technař. Miles popisuje mainstreamovou kulturu mládeže jako soustavnou stylovou brikoláž a hru s významy, bez nutnosti jakéhokoliv subkulturního ideologického závazku. (Sub)kulturní ideologie, již v sobě hudba a oblečení obsahují, není pro mladé lidi, co do vnější prezentace, tak důležitá, i když svou vizáží a hudební preferencí „kupuji““ kompletní sémiologický balík a jsou si vědomi významů každého stylu. Jednoduše však nevidí potřebu tyto významy vykřikovat jako podmínku své autenticity (Miles 2000: 102-103). Ačkoliv většina mládeže vyvolává navenek dojem zdánlivé heterogenity, to, co charakterizuje jádro hodnot těchto mladých lidí, je inkorporace do mainstreamu. „Většina mladých lidí nemá nic, proti čemu by revoltovala. $\mathrm{V}$ tomto kontextu jsou mladí lidé názorově nezávislí a současně paradoxně konformisté, protože žijí ve světě, v němž individuální zkušenosti vystavené okolním vlivům jsou čím dál více homogenní“ (Miles 2000: 115). Muggleton (2000) poznamenává, že pro moderní éru subkultur jsou charakteristické tyto znaky: skupinová identita, stylová homogenita, silné hranice trvání, poskytnutí hlavní identity, vysoký stupeň ztotožnění, členství vnímané jako stálé, nízký stupeň subkulturní mobility, důraz na přesvědčení a hodnoty, politické vyjádření odporu, zaměřenost proti médiím, autentické vnímání sebe sama. Charakteristickými znaky postmoderny jsou roztř̌rštěná identita, stylová heterogenita, slabé hranice trvání, mnoho stylových identit, nízký stupeň ztotožnění, přechodná náklonnost k subkultuře, fascinace stylem a image, apolitické cítění, pozitivní postoj k médiím, vědomí neautentičnosti.

Pokud bychom přijali předloženou vnitřní logiku mainstreamové kultury mládeže, pak Muggletonovo vymezení subkultur na moderní a postmoderní vyznívá př́liš kategoricky. Jelikož je mainstream svou podstatou multidimenzionální, zahrnuje v sobě nejen hudbu a módu, ale také jazyk, normy a hodnoty a všechny tyto složky mezi sebou různě kombinuje. A tak Honza může poslouchat alternativní hudbu, ale být fascinován stylem a image a s každou změnou se vnímat stále stejně autenticky. Jana naopak nesleduje módu, ale pravidelně poslouchá komerční rádiovou stanici a zároveň ráda navštěvuje alternativní hudební kluby.

Pro Grossberga $(1984,1997)$ znázorňuje mainstream (konkrétně populární kultura) formu sociální pastiše. Zlomky ležící na okraji hlavního proudu (subkultury) jsou částečně inkorporovány skrze imitaci stylů a hudby. Jiné fragmenty se naopak samy o sobě z hlavního proudu vydělují a ocitají se zpět na okraji. Mainstream je z tohoto pohledu strukturovanou distribucí praktik, kódů a vzájemných účinků. Grossberg namítá, že mainstream nelze popisovat jako „unifikované a monolitické Ostatní“ (Grossberg 1997, in Muggleton a Weinzierl 2003: 31).

Tam, kde dochází k překrytí zlomků a hlavního proudu, se vytváří prostor odhalující sociální a kulturní rozdíly, na něž citlivě reaguje především mládež. Koncept mainstreamové kultury mládeže tak vybízí $\mathrm{k}$ řadě otázek. Nejlepší sociologické otázky jsou ovšem ty, jež zkoumají nejen uvědomělé, subjektivní a kreativní aspekty lidského jednání, ale zároveň jejich zasazením do širšího kontextu pomáhají porozumět procesům přítomným v celé společnosti. 


\section{Literatura}

Barker, Ch. 2006. Slovník kulturálních studii. Praha: Portál.

Benjamin, W. 1979. „Umělecké dílo v době mechanické reprodukovatelnosti.“ In: Dílo a jeho zdroj. Odeon, Praha, s. 18-34.

Bennett, A. 1999. „Subcultures or Neo-Tribes?: Rethinking the Relationship between Youth, Style and Musical Taste." Sociology, vol. 33 (3): 599-617.

Bennet, A.; Kahn-Harris, K. 2004. After Subculture: Critical Studies in Contemporary Youth Culture. New York: Palgrave Macmillan, s. 1-18.

Brake, M. 1985. Comparative Youth Culture: The Sociology of Youth Cultures and Youth Subcultures in America, Britain and Canada. London: Routledge.

Hebdige, D. 1998. „Object as Image: The Italian Scooter Cycle.“ In Hiding in the Light: On Images and Things. New York: Routledge.

Hebdige, D. 1979. Subculture: The Meaning of Style. London: Routledge.

Jenks, Ch. 2005. Subculture: The Fragmentation of the Social. London: Sage Publications. Longman Family Dictionary. 1991. Praha: Aventium, s. 415.

Máchalová, J. 2002. Módou posedli: čtení o módě 20. století. Břeclav: Moraviapress.

Miles, S. „Researching Young People as Consumers: Can and Should We Ask Them Why?“ In A. Bennett, M. Cieslik, S. Miles (eds.) Researching Youth. Basingstoke: Palgrave a McMillan.

Miles, S. 2000. Youth Lifestyles in a Changing World. Buckingham: Open University Press.

Muggleton, D. 2000. Inside Subculture: The Postmodern Meaning of Style. Oxford: Berg.

Muggleton, D. 2005. „From Classlessness to Clubculture: A Genealogy of Post-war British Youth Cultural Analysis.“ In Young, 13: 205-219.

Muggleton, D.; Weinzierl, R. 2003. ,What Is ,Post-subcultural Studies“ Anyway?“ In The postsubcultures Reader. Oxford: Berg, s. 3-26.

Redhead, S. 1997. Subculture to Clubcultures: An Introduction to Popular Cultural Studies. Oxford: Blackwell Publishers.

Simmel, Georg. 1997. „Móda“. In Penize v moderní kultuře a jiné eseje. Praha: Slon. Velký sociologický slovnik. 1996. Druhý díl, P-Ž. Praha: Karolinum.

Thornton, S. 1996. Club Cultures: Music, Media, and Subcultural Capital. Hanover: University Press of New England.

\section{Internetové zdroje}

http://www.modculture.co.uk/culture/culture.php?id=22

http://en.wikipedia.org/wiki/Mainstream

\section{Autorka}

Michaela Pyšňáková je absolventkou magisterského programu sociologie na FSS MU. V současnosti studuje v doktorském studijním programu sociologie na téže fakultě. Specializuje se na problematiku životních stylů současné mládeže, na sociologii spotřeby, inter/intra generačního konfliktu, sociální/kulturní exkluzi a inkluzi skrze spotřební chování. V magisterské práci „Cool Place - mizející hranice mezi identitou a image“ (2006) založené na terénním výzkumu popisuje současnou městskou klubovou kulturu mládeže. Kontakt: michaela.pysnakova@gmail.com 